\title{
The Skeletal Phenotype in Neurofibromatosis Type 1 - Structural Defects, Molecular Mechanisms and Therapeutic Approaches
}

Wenke Seifert ${ }^{1}$, Mateusz Kolanczyk and Jirko Kühnisch ${ }^{2 *}$

${ }^{1}$ Institute for Vegetative Anatomy, Charité - University Medicine of Berlin, Berlin, 10115, Germany

${ }^{2}$ Experimental and Clinical Research Center (ECRC) Max-Delbrück-Centrum for Molecular Medicine (MDC), Charité - Universitätsmedizin Berlin, Berlin, Germany

\begin{abstract}
Patients with Neurofibromatosis Type 1 (NF1) develop subcutaneous benign tumors and dysfunction of multiple organs. About $30 \%$ of NF1 patients are affected by skeletal manifestations such as osteopenia, kyphoscoliosis, tibia bowing, or pseudarthrosis of the tibia. NF1 is caused by autosomal dominant mutation of the NF1 gene encoding the protein neurofibromin a regulator of the RAS/MAPK/ERK pathway. During the last decade pre-clinical studies provided multiple insights into the molecular mechanisms of the NF1 associated skeletal phenotype. They also allowed analysis of bone structural defects in tissue specific knockout mice and their comparison with the changes observed in patient samples. Importantly, preclinical models allowed exploration of the potential therapeutic approaches.

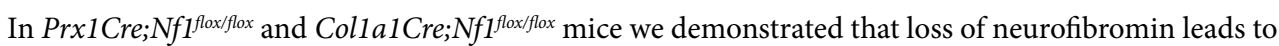
multi scale defects in cortical bone: i) increased marco-porosity, ii) increased micro-porosity (osteocyte lacunae), iii) diminished mineralization, and iv) reduced organic matrix maturation. These changes significantly weaken overall mechanical strength of bone tissue in murine models. In NF1 patient bone samples similar changes were observed which may result in fractures. Inhibition of the RAS/MAPK/ ERK pathway with Lovastatin, Trametinib, PD198306, P98059, and PD0325901 normalized bone healing in Nf1 knockout mouse models. Downregulation of the RAS/MAPK/ERK pathway restored normal osteoblast differentiation/function and prevented accumulation of fibroblasts within the bone fracture site. Another approach tested in mouse models was to stimulate osteoblastic bone formation with bone morphogenic protein 2 or 7 (BMP-2, BMP-7) and block bone resorption with bisphosphonates. Recently Asfotase- $\alpha$, replacing alkaline phosphatase (ALP) function specifically in bone tissue, was used to restore normal bone mass in inducible Tet-Off based Osx-Cre;Nf1 flox/flox mice.
\end{abstract}

In summary, neurofibromin controls development of the skeletal system by regulating the RAS/MAPK/ ERK pathway in chondrocytes, pre-osteoblasts, osteoblasts, and osteocytes. Preclinical model studies, exploring therapeutic approaches based on targeting RAS/MAPK/ERK pathway and ALP activity yield promising results which will likely instruct future clinical trial designs.

NF1 is a Tumor Disease with Tumor-independent MultiOrgan Involvement

Neurofibromatosis type 1 (NF1) is a tumor disorder (MIM\#162200) that is caused by autosomal dominant loss-of-function mutations in the NF1 gene encoding the RAS_GTPase-Activating Protein (Ras-GAP) neurofibromin [1]. Mutation or loss-of-function of neurofibromin leads to hyperactive RAS protein and the subsequent downstream MAPK/MEK signaling pathway [1,2]. Activation of RAS/MAPK/ MEK signaling affects in a cell dependent manner PI3K-mTOR, c-Jun $\mathrm{N}$-terminal kinase (JNK), JAK-STAT3 signaling, cAMP-PKA, RhoROCK-LIMK2-Cofilin, or Rac1-Pak1-LIMK1-Cofilin pathways [3].

Constitutional NF1 mutations cause the tumor susceptibility in NF1 patients. Most frequently, NF1 patients are affected by cutaneous, benign neurofibromas, which are composed of Schwann cells, other nerve cells, fibroblasts, mast cells, and endothelial cells [4]. Plexiform tumors, which are another group of frequent tumors in NF1, represent a severe life risk for NF1 patients after transformation into malignant peripheral nerve sheath tumors (MPNST) $[5,6]$.

Although primarily identified as a tumor entity NF1 patients present with multi-organ involvement affecting a broad range of tissues such as skin, skeleton, cardiovascular system, nervous system, and ophthalmic system [7,8]. Although not associated with life

\section{Publication History:}

Received: October 05, 2016

Accepted: December 05, 2016

Published: December 072016

Keywords:

Neurofibromatosis, neurofibromin , In vitro, In vivo, knock-out mouse treating consequences the abnormalities of the skeleton are frequent, may result in pseudarthrosis of the tibia, and have a significant impact on the mobility of NF1 patients $[9,10]$. During the last decade the application of $N f 1$ knock-out mouse models allowed the systematic exploration of the molecular mechanisms causing the skeletal defects in NF1 and explored potential therapeutic approaches for NF1 pseudarthrosis. Moreover, adjusting observation from Nf1 knockout mice with findings in patient samples revealed details of the pathomechanism which significantly increased our understanding of the skeletal NF1 phenotype.

\section{The Skeletal NF1 Phenotype of Man}

The skeletal phenotype in NF1 patients is highly variable and may "Corresponding Author: Dr. Jirko Kühnisch, Experimental and Clinical Research Center (ECRC), Max-Delbrück-Centrum for Molecular Medicine (MDC), Lindenberger Weg 80, 13125 Berlin, Germany; Tel: +49(030)9406-3319 E-mail: jirko.kuehnisch@mdc-berlin.de

Citation: Seifert W, Kolanczyk M, Kühnisch J (2016) The Skeletal Phenotype in Neurofibromatosis Type 1 - Structural Defects, Molecular Mechanisms and Therapeutic Approaches. Int J Surg Surgical Porced 1: 113. doi: http://dx.doi. org/10.15344/ijssp/2016/113

Copyright: (C) 2016 Seifert et al. This is an open-access article distributed under the terms of the Creative Commons Attribution License, which permits unrestricted use, distribution, and reproduction in any medium, provided the original author and source are credited. 
Citation: Seifert W, Kolanczyk M, Kühnisch J (2016) The Skeletal Phenotype in Neurofibromatosis Type 1 - Structural Defects, Molecular Mechanisms and Therapeutic Approaches. Int J Surg Surgical Porced 1: 113. doi: http://dx.doi.org/10.15344/ijssp/2016/113

Page 2 of 7

comprise osteopenia, osteoporosis, dystrophic and non-dystrophic scoliosis, partial overgrowth of an extremity, short stature, sphenoid wing dysplasia, debilitating focal bone lesions, or pseudarthrosis [11-17]. Studies systematically assessing the bone status of larger NF1 cohorts detected significantly diminished bone mineral density (BMD) and whole body bone mineral content (BMC) in NF1 patients $[12,15]$. In addition, Seitz et al. showed increased bone turnover and hyperosteoidosis in NF1 patients [15]. Importantly, load bearing parts of the skeleton, which have a higher turnover and adaptation, appear to be more affected by diminished bone mass and mineralization [18]. Consistently, fracture risk in NF1 patients is determined by osteopenia/osteoporosis and local trabecular architecture [14].

Biochemical assessment of NF1 patient samples demonstrated moderately elevated parathyroid hormone $(\mathrm{PTH})$ that normalized after supplementation with calcium and 25(OH)-Vitamin D3 [12]. However, within 2 years BMD Z-scores did not improve adequately in these patients. Decreased 25(OH)-Vitamin D3 values were especially observed in NF1 patients with high dermal tumor load [19]. Another study showed reduced 25(OH)-Vitamin D3 and increased PTH values that were accompanied by increased calcium and phosphate levels [15]. Therapeutic supplementation of four NF1 patients from this cohort with 25(OH)-Vitamin D3 and calcium normalized calcium and phosphate, increased 25(OH)-Vitamin D3, and diminished PTH values. This treatment improved $\mathrm{T}$ - and $\mathrm{Z}$-scores of $\mathrm{BMD}$ [15]. This study indicates that NF1 patients have dysregulated biochemical bone markers and that 25(OH)-Vitamin D3 supplementation results inpartial improvement of BMD.

Apart from more generalized skeletal signs such as osteoporosis/ osteopenia and scoliosis, focal bone defects are a critical problem in NF1 $[10,11,20]$. Localized bone defects critically disturb mechanical properties of bone and likely determine the place of fracture occurrence [21,22]. About $5 \%$ of patients with congenital NF1 present with pseudarthrosis that most frequently affects the tibia [9] Already early reports linked pseudarthrosis to NF1 although at this time the limited clinical understanding of NF1 and the absence of genetic data precluded unequivocally proof of causal relationship [23]. Anterolateral bowing of the tibia precedes fracture and subsequent pseudarthrosis [24]. However, long bone bowing does not necessarily lead to fracture and may affect also ulna, radius, humerus, femur, or clavicle [25] suggesting defective skeletal development or turnover of long bone tissue. Consistently, in a case-control study bony deformations and fractures were observed in the first years of life [9] supporting the idea that loss of the NF1 gene causes a genetically determined bone dysplasia. This was strengthened by the identification of NF1 double inactivation in pseudarthrotic tissue of NF1 patients [26]. Anterolateral bowing is a specific feature of NF1 and together with focal bone defects a critical determinant of NF1 pseudarthrosis $[16,27]$

\section{Modelling the Skeletal NF1 Phenotype in Mice}

The availability of genetically manipulated Nf1 mouse models provided in the recent decade a critical tool to dissect the complex skeletal phenotype and their cellular origin. While the total homozygous knock-out of $\mathrm{Nf1}\left(\mathrm{Nf1}^{--}\right)$is lethal due to failure of heart and cardiovascular development, the heterozygous Nf1 knock-out mice $\left(N \mathrm{N1}^{+/}\right)$are viable and represent an excellent model to explore systemic monoallelic $\mathrm{Nf1}$ ablation. $\mathrm{N} f \mathrm{1}^{+/}$mice do not develop an overt bone phenotype in vivo but show osteoprogenitor cell differentiation defects in vitro [28]. Conditional homozygous ablation of Nf1 in

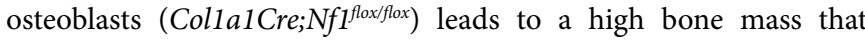
is accompanied by hyperostoidosis [29]. This phenotype is due to impaired differentiation of osteoprogenitor cells and application of the Ras/MAPK/MEK signaling pathway inhibitor PD198306 normalized hyperostoidosis.

Col1a1Cre; $N f^{f l o x f f l o x}$ mice allowed evaluation of the impact of $N f 1$ specifically in osteoblasts. Other conditional mouse models such

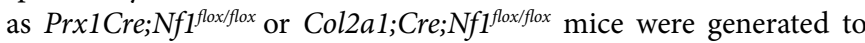
explore its role for mesenchymal progenitor/stem cells and osteo chondroprogenitor cells, respectively [30,31]. Prx 1 Cre; $N f 1^{f l o x / f l o x}$ mice develop a complex phenotype comprising hip joint fusion, tibia bowing, hyperporosity of the long bone cortex, long bone shortening, hyperosteoidosis, dimished trabecular bone mass, thinning of the proliferative/hypertrophic cartilage, and abnormalities of the long bone vascular system [3]. The vertebra of Prx1Cre; Nf1 floxfflox mice demonstrates diminished trabecular bone mass but normal overall development as the Prx1 promoter drives Cre expression mainly in the mesenchyme of the skull and limb buds. In contrast, Col2a1Cre; Nf1 flox/flox and Colla1Cre; $N f 1^{f l o x f f l o x}$ mice demonstrate defects of the vertebra characterized by short vertebral segments, reduction in cortical as well as trabecular bone mass, diminished mechanical strength, and enlarged intervertebral canals [32-34]. The overall phenotype mirrors several features of scoliosis in NF1 patients.

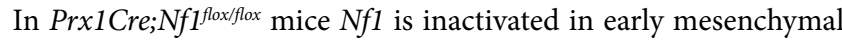
progenitor cell stages affecting proliferation and differentiation of multiple down-stream cell types such as stromal cells, osteoblasts, chondrocytes, endothelial cells, and skeletal muscle cells [3,35]. This explains the severe phenotype of Prx1Cre; Nf1 floxfflox mice that on the one hand models the complex musculoskeletal phenotype observed in NF1 patients but limits molecular and cellular analysis due to the broad spectrum of affected cell types. Hierarchical analysis of multiscale bone defects in Prx1Cre; $N f 1^{f l o x f f l o x}$ humeri (the tibia has no physiological loading due to hip joint fusion) demonstrated increase in macro-porosity due to focal mineralization defects as well as persistent blood vessels, diminished bone tissue mineralization, impaired collagen maturation, enlarged osteocyte lacunae size, increased osteocyte number, and reduced osteocyte dendrite connectivity $[36,37]$. These observation stress findings from NF1 patients suggesting focal bone defects as critical fracture determinant. Apart from bone quantity and quality, musclestrengt hand power critically determine long bone bowing, the risk to fall, and fracture risk [38,39]. Neurofibromin is a positive regulator of myogenesis and significantly contributes to overall locomotive inabilities of NF1 patients $[35,40,41]$.

\section{Therapeutic Approaches Targeting Fracture Healing in Mice}

Genetically manipulated $N f 1$ mouse models provided in the recent decade a key tool to identify mechanisms leading to the complex NF1 associated skeletal phenotype. In addition, these tools were systematically applied to explore possibilities to counteract the skeletal defects and promote healing of pseudarthrotic fracture. Systemic heterozygous $\mathrm{Nf1}$ knock-out in $\mathrm{Nf1^{+/ }}$ mice delays fracture healing due to insufficient cartilage removal, accumulation of fibrous tissue, and diminished bone formation (Table 1) [42]. Similar observations

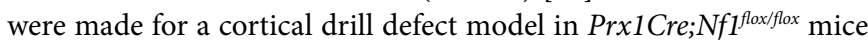
demonstrating delayed bone healing, excessive formation/persistence of fibro-cartilaginous tissue, and defective matrix mineralization [30]. 
Citation: Seifert W, Kolanczyk M, Kühnisch J (2016) The Skeletal Phenotype in Neurofibromatosis Type 1 - Structural Defects, Molecular Mechanisms and Therapeutic Approaches. Int J Surg Surgical Porced 1: 113. doi: http://dx.doi.org/10.15344/ijssp/2016/113

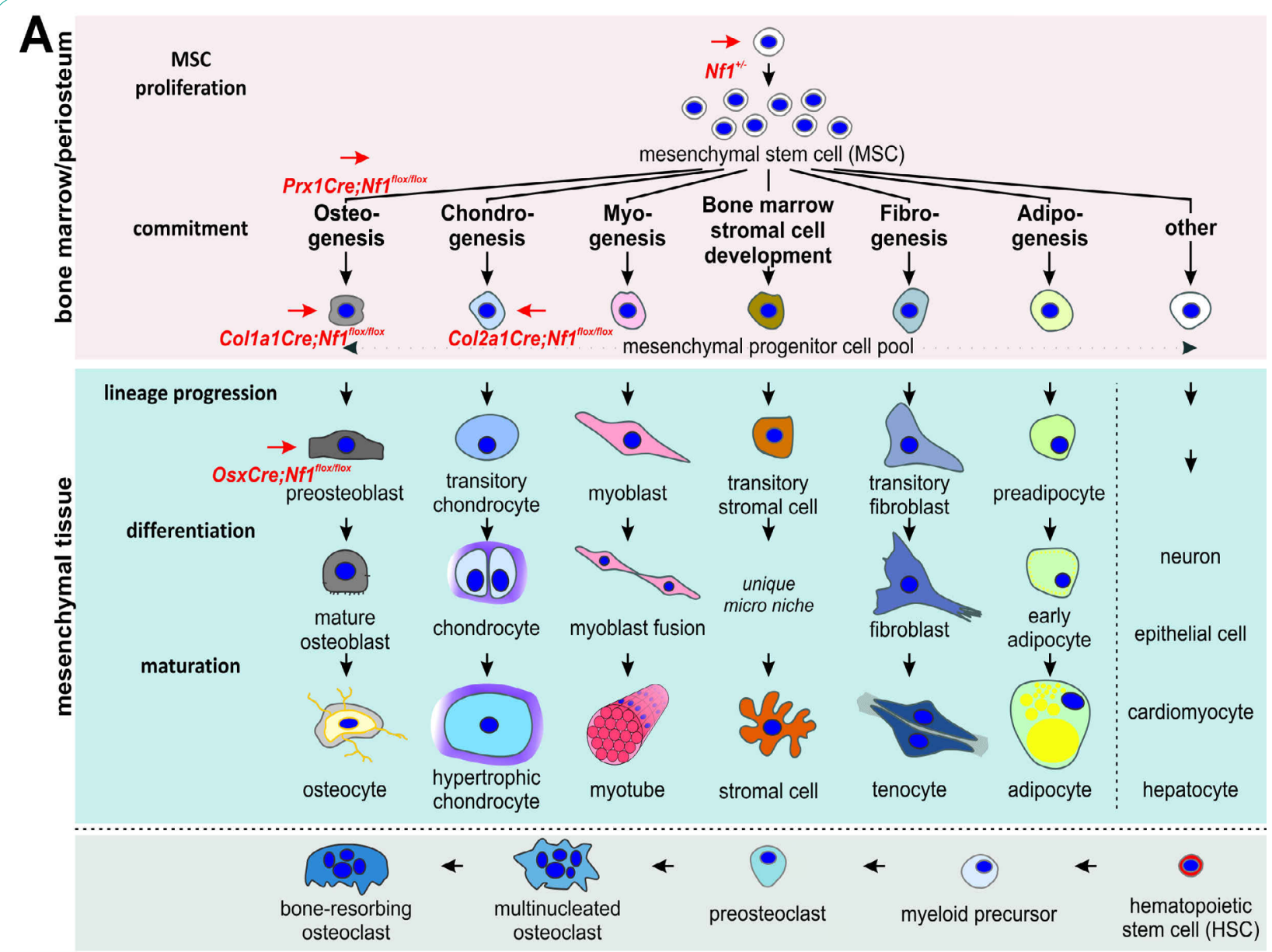

B

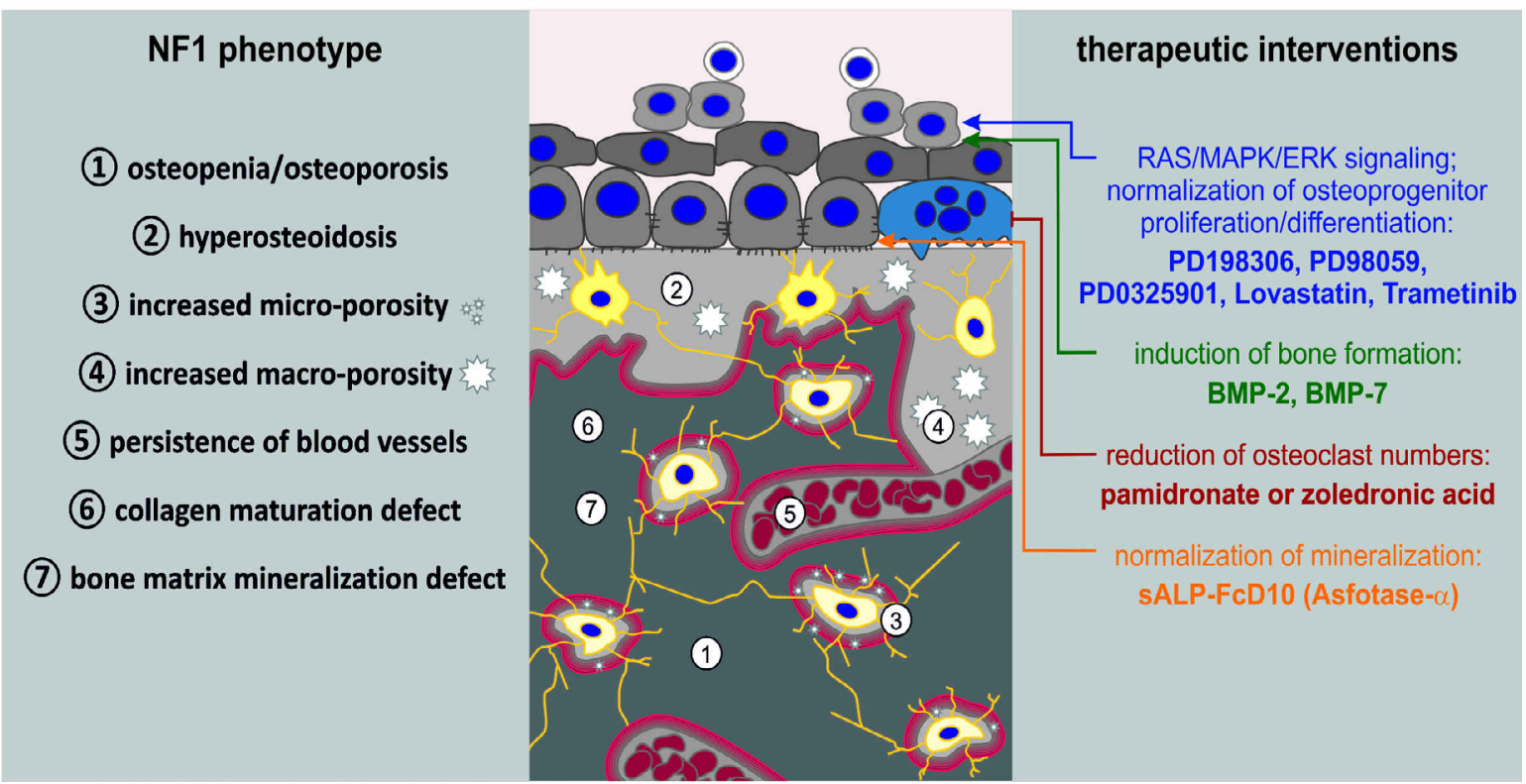

Figure 1: A Scheme of mesenchymal differentiation. Mesenchymal stem cells (MSC) give rise to osteoblasts/osteocytes, chondrocytes, myocytes, stromal cells, tenocytes, and adipocytes. The cellular stage at which the $N f 1$ gene becomes inactivated in different mouse models are shown

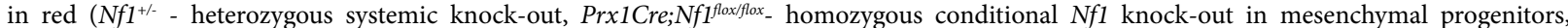
Col1a1Cre; Nf1 flox/flox - homozygous conditional knock-out in osteoblast progenitors, Col2a1Cre; Nf $1^{f l o x}$ flox - homozygous conditional Nf1 knock-out in chondrogenic progenitors). B Scheme of bone phenotype features upon $N f 1$ knock-out and therapeutic interventions. Phenotypical characteristics 1-7 of found in different NF1 mouse models are listed on the left. Pharmacological approaches tested in mouse models as well as in NF1 patients and their sites of action are shown on the right. 
Citation: Seifert W, Kolanczyk M, Kühnisch J (2016) The Skeletal Phenotype in Neurofibromatosis Type 1 - Structural Defects, Molecular Mechanisms and Therapeutic Approaches. Int J Surg Surgical Porced 1: 113. doi: http://dx.doi.org/10.15344/ijssp/2016/113

\begin{tabular}{|c|c|c|c|}
\hline Therapeutic approach & Model system & Addressed molecular pathway and outcome & Reference \\
\hline $\begin{array}{l}\text { systemic oral application of MEK } \\
\text { inhibitor PD198306 }(20 \mathrm{mg} / \mathrm{kg} / \text { day }) \\
\text { for } 5 \text { weeks starting with } 4 \text { weeks } \\
\text { of age }\end{array}$ & $\begin{array}{l}\text { Colla1Cre; } N f 1^{f l o x / f l o x} \text { permanent knock- } \\
\text { out in osteoblast progenitors; no fracture }\end{array}$ & $\begin{array}{l}\text { normalization of MAPK/MEK signaling reduces } \\
\text { hyperosteoidosis }\end{array}$ & {$[29]$} \\
\hline no intervention & $\begin{array}{l}\text { fracture model of } \mathrm{Nf1}^{+/-} \text {diaphyseal and } \\
\text { distal tibia }\end{array}$ & $\begin{array}{l}\text { delayed fracture healing of distal tibia due } \\
\text { to delayed cartilage removal, fibrous tissue } \\
\text { accumulation, insufficient bone formation }\end{array}$ & {$[42]$} \\
\hline $\begin{array}{l}\text { intramuscular BMP-2 }(20 \mathrm{mg})+ \\
\text { systemic zoledronic acid }(0.02 \mathrm{mg} / \\
\mathrm{kg}) \text { twice a week }\end{array}$ & $\begin{array}{l}\text { intramuscular induction of heterotopic } \\
\text { bone in } \mathrm{Nf}^{+/-} \text {quadriceps }\end{array}$ & $\begin{array}{l}\text { BMP-2 induced less heterotopic bone in } \mathrm{NfI}^{+/-} \\
\text {mice, combined treatment of zoledronic acid with } \\
\text { BMP-2 synergistically increased heterotopic bone }\end{array}$ & {$[46]$} \\
\hline no intervention & $\begin{array}{l}\text { defect model in tibia cortex of } \\
\text { Prx } 1 \text { Cre;Nf1 flox/flox mice }\end{array}$ & $\begin{array}{l}\text { delayed cortical boned efect healing due to } \\
\text { accumulation/persistence of fibrocartilaginous } \\
\text { tissue and delayed bone formation }\end{array}$ & {$[3]$} \\
\hline $\begin{array}{l}\text { systemic lovastatin application } \\
\text { (daily oral gavage } 0.15 \mathrm{mg} \text { activated } \\
\text { lovastatin) }\end{array}$ & $\begin{array}{l}\text { defect model in tibia cortex of } \\
\text { Prx } 1 \text { Cre;Nff } 1^{f l o x / f l o x} \text { mice }\end{array}$ & $\begin{array}{l}\text { inhibition of Ras/MAPK/MEK signaling with } \\
\text { lovastatin normalized delayed fracture healing in } \\
\text { Prx1Cre;Nf1 } 1^{f l o x f f l o x} \text { mice }\end{array}$ & {$[3]$} \\
\hline $\begin{array}{l}\text { single local low-dose lovastatin } \\
\text { delivery via microparticles }(10 \mathrm{mg} / \\
\mathrm{kg})\end{array}$ & $\begin{array}{l}\text { tibia fracture model of } 2 \text { month } \\
\text { Colla1Cre; } N f f^{\text {flox/flox }} \text { mice }\end{array}$ & $\begin{array}{l}\text { localized inhibition of MAPK/ERK signaling } \\
\text { decreased osteoid volume and increased callus } \\
\text { bone mass in Colla1;Nf1 } 1^{\text {flox/flox }} \text { mice }\end{array}$ & {$[33]$} \\
\hline $\begin{array}{l}\text { surgery of congenital tibia } \\
\text { pseudarthrosis followed by BMP- } \\
7(\mathrm{OP}-1) \text { administration and } \\
\text { pamidronate or zoledronic acid } \\
\text { application }\end{array}$ & $\begin{array}{l}7 \text { patients with congenital pseudarthrosis } \\
\text { of the tibia ( } 6 \text { patients diagnosed as } \\
\text { NF1), median age } 7 \text { years }\end{array}$ & $\begin{array}{l}6 \text { patients healed to primary healing within } 5.5 \\
\text { month } \\
\text { BMP-7 and bisphosphonates support fracture } \\
\text { healing after pseudarthrosis surgery in NF1 } \\
\text { patients }\end{array}$ & {$[50]$} \\
\hline no intervention & $\begin{array}{l}\text { open and closed tibia fracture model of } \\
\text { AdenoCre;Nf1 } 1^{f l o x /} \text { and AdenoCre;Nf1 }{ }^{f l o x /} \\
\text { flox mice }\end{array}$ & $\begin{array}{l}\text { closed fracture: strongly reduced fracture union } \\
\text { rates, increase of non-bony/fibrous tissues in } \\
\text { callus, increased cell proliferation in callus, } \\
\text { increased osteoclasts } \\
\text { open fracture: strongly reduced fracture union } \\
\text { rates, increase of non-bony/fibrous tissues in } \\
\text { callus, mild increase in cell proliferation in callus, } \\
\text { massive increase in osteoclasts }\end{array}$ & {$[47]$} \\
\hline $\begin{array}{l}\text { constant subcutaneous } \\
\text { administration (osmotic pump) of } \\
\text { PD98059 (10 mg/kg/day) }\end{array}$ & $\begin{array}{l}\text { tibia fracture model of Colla1Cre; } N f 1^{\text {flox/- }} \\
\text { mice }\end{array}$ & $\begin{array}{l}\text { inhibition of MEK signaling with PD98059 } \\
\text { normalizes Erk activation and promotes } \\
\text { Ob differentation; PD98059 normalizes Oc } \\
\text { differentiation }\end{array}$ & {$[44]$} \\
\hline $\begin{array}{l}\text { individual or combined } \\
\text { administration of rhBMP-2 } \\
(10 \mu \mathrm{g}) \text { and the MEK inhibitor } \\
\text { PD0325901( } 10 \mathrm{mg} / \mathrm{kg} / \text { day from two } \\
\text { days before fracture to ten days after } \\
\text { fracture })\end{array}$ & $\begin{array}{l}\text { tibia mid shaft fracture model of } \\
\text { AdenoCre; } N f 1^{f l o x /} \text { and AdenoCre;Nf1 flox/flox } \\
\text { mice } \\
\text { closed and open fracture model }\end{array}$ & $\begin{array}{l}\text { results: delivery vehicle alone, PD0325901, } \\
\text { rhBMP-2, or PD0325901+rhBMP-2 gave fracture } \\
\text { union rates of } 0 \%, 8 \%, 69 \%(\mathrm{p}<0.01) \text {, or } 80 \%(\mathrm{p}< \\
0.01) \text {, respectively } \\
\text { PD0325901+rhBMP-2 induces increased } \\
\text { callus size but did not reduce fibrotic tissue } \\
\text { accumulation }\end{array}$ & {$[41]$} \\
\hline $\begin{array}{l}\text { local rhBMP-7 treatment after } \\
\text { pseudarthrosis surgery }\end{array}$ & $\begin{array}{l}\text { randomized study of } 20 \text { patients } \\
\text { associated with NF1 to test beneficial } \\
\text { impact of BMP-7 after surgery, Kirschner } \\
\text { fixation, autologous bone grafting }\end{array}$ & $\begin{array}{l}\text { no difference in healing time between BMP- } 7 \text { and } \\
\text { control group } \\
\text { no pre- to post-operative improvement between } \\
\text { BMP-7 and control group }\end{array}$ & {$[52]$} \\
\hline $\begin{array}{l}\text { rhBMP-2 }(5 \mathrm{mg}) \text { loaded on collagen } \\
\text { sponges } \\
\text { zoledronic acid was given at } 0.02 \mathrm{mg} / \\
\mathrm{kg} \text { (total dose } 0.1 \mathrm{mg} / \mathrm{kg} \text { ) by biweekly } \\
\text { subcutaneous injection starting } 3 \\
\text { days postoperatively }\end{array}$ & $\begin{array}{l}\text { posterolateral fusion model of lumbar } \\
\text { spine L4 to L6 in } N f 1^{+/} \text {mice }\end{array}$ & $\begin{array}{l}\text { combined rhBMP- } 2 \text { and zoledronic acid treatment } \\
\text { maximized bone formation by diminishing } \\
\text { osteoclast numbers }\end{array}$ & {$[48]$} \\
\hline $\begin{array}{l}\text { systemic treatment with sALP-FcD10 } \\
\text { (bone targeted alkaline phosphatase) } \\
\text { of newborn mice ( } 8.2 \mathrm{mg} / \mathrm{kg} / \text { day for } \\
18 \text { days) }\end{array}$ & $\begin{array}{l}\text { Col2a1Cre; } N f 1^{\text {flox/flox }} \\
\text { permanent knock-out in chondrogenic } \\
\text { progenitors; } \\
\text { no fracture }\end{array}$ & $\begin{array}{l}\text { normalization of mineralization by degradation of } \\
\text { accumulating PPi } \\
\text { partial rescue of growth retardation, cortical } \\
\text { thickness, cortical geometry, mineral density }\end{array}$ & {$[32]$} \\
\hline
\end{tabular}

continue... 
Citation: Seifert W, Kolanczyk M, Kühnisch J (2016) The Skeletal Phenotype in Neurofibromatosis Type 1 - Structural Defects, Molecular Mechanisms and Therapeutic Approaches. Int J Surg Surgical Porced 1: 113. doi: http://dx.doi.org/10.15344/ijssp/2016/113

Page 5 of 7

\begin{tabular}{|c|c|c|c|}
\hline $\begin{array}{l}\text { systemic treatment with sALP-FcD10 } \\
\text { (bone targeted alkaline phosphatase) } \\
\text { from P14 for } 6 \text { weeks) ( } 8.2 \mathrm{mg} / \mathrm{kg} / \\
\text { day for } 18 \text { days) }\end{array}$ & $\begin{array}{l}\text { inducible Tet-Off-based OsxCre; } N f f^{f l o x / f l o x} \\
\text { repression of } N f 1 \text { knock-out from } \\
\text { conception to postnatal day } 14 \\
\text { no fracture }\end{array}$ & $\begin{array}{l}\text { normalization of mineralization by degradation of } \\
\text { accumulating PPi } \\
\text { rescue of trabecular bone mass, hyperosteoidosis, } \\
\text { bone mineral density, mechanical parameter }\end{array}$ & [32] \\
\hline $\begin{array}{l}\text { independent or combined treatment } \\
\text { with } 20 \mu \mathrm{lBMP} 2 \text {-polygycidol } \\
(0.50 \mu \mathrm{g} / \mu \mathrm{l}) \text { or } 20 \mu \mathrm{l} \text { Trametinib } \\
\text { nanoparticles (MEK inhibitor, } 0.188 \\
\mu \mathrm{g} / \mu \mathrm{l}) \text { at day } 1 \text { and } 7 \text { post-fracture, } \\
\text { analysis } 21 \text { days post-fracture }\end{array}$ & $\begin{array}{l}\text { inducible Tet-Off-based OsxCre;Nf1 flox/flox } \\
\text { repression of } N f 1 \text { knock-out from } \\
\text { conception to postnatal day } 14 \\
\text { mid-diaphyseal tibia fracture of } 2 \text { month } \\
\text { mice, intramedullary fixation }\end{array}$ & $\begin{array}{l}\text { Tet-Off-based OsxCre;Nf1 floxflox } \\
\text { mice treated with doxycycline develop normally } \\
\text { but demonstrate defective fracture healing } \\
\text { only combined treatment with rBMP2-polygycidol } \\
\text { and Trametinib normalized fracture healing }\end{array}$ & [49] \\
\hline $\begin{array}{l}\text { treatment with rhBMP-2 and } \\
\text { intramedullary fixation in NF1 } \\
\text { patients with congenital tibia } \\
\text { pseudarthrosis }\end{array}$ & $\begin{array}{l}15 \text { NF1 patients with congenital tibia } \\
\text { pseud-arthrosis nonunion fractures } \\
\text { underwent surgery with subsequent } \\
\text { rhBMP-2 treatment }\end{array}$ & $\begin{array}{l}\text { outcome: } 3 \text { patients underwent successful healing } \\
\text { with rhBMP-2, } 5 \text { patients failed to heal, } 3 \text { patients } \\
\text { amputated, } 5 \text { patients had persistent nonunions, } 3 \\
\text { patients refractured } \\
\text { rhBMP-2 may support fracture healing after } \\
\text { surgery in NF1 patients }\end{array}$ & [51] \\
\hline
\end{tabular}

Table 1: Therapeutic approaches in NF1 patients and disease mouse models.

Accumulation of fibrous and undifferentiated tissue was further proved in an open and closed tibia fracture model of AdenoCre; $\mathrm{Nf}^{f l o x /}$

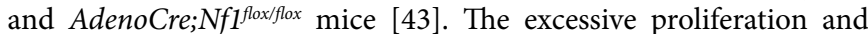
persistence of fibro-cartilaginous tissue appears to be a critical early determinant of defective fracture healing upon loss of $N f 1$ as it likely prevents proper homing and/or proliferation of mesenchymal progenitor cells. The exact mechanisms of early inflammatory events and cell lineages contributing to fracture callus formation upon loss of $N f 1$ have not been explored so far.

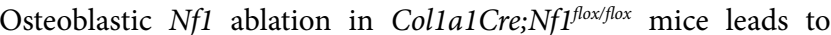
hyperactive RAS/MAPK/MEK signaling inducing hyperosteoidosis and treatment with the MEK inhibitor PD198306 partially rescued this phenotype [29]. In a cortical tibia defect model of Prx1Cre; $N f 1^{f l o x / f l o x}$ mice systemic lovastatin, reducing RAS activity by ceased prenylation and farnesylation, administration diminished fibro-cartilaginous tissue, reduced osteoid, and improved cortical bone repair [30]. A complementary approach with local low-dose lovastatin delivery in Colla1Cre; $N f 1^{f l o x / f l o x}$ mice (tamoxifen induced) improved mineralized tissue within the callus, diminished osteoid, and improved mechanical strength of the fracture [33]. Subcutaneous administration of another MEK inhibitor PD98059 in Colla1 Cre; $N f 1^{f l o x /}$ mice normalized MAPK signaling and promoted osteoblast differentiation leading to improved tibia fracture healing [34]. Moreover, PD98059 treatment normalized osteoclast maturation from $\mathrm{Nf1}^{+/-}$bone marrow mononuclear cells suggesting an impact of the monocyte/osteoclast lineage on fracture healing in NF1. Together these studies suggested that suppression of the RAS/MAPK/MEK signaling pathway might positively impact the fracture healing process and prevent development of pseudarthrosis.

In a second approach bone morphogenic proteins 2 and 7 (BMP-2 , BMP-7), which are osteoanabolic cytokines, were tested to improve bone healing upon loss of Nf1. BMP-2 and BMP-7 induce bone formation by promoting osteoprogenitor proliferation and differentiation [45]. In $\mathrm{Nf}^{+/}$mice BMP-2 induced less heterotopic bone compared to control $\mathrm{Nf}^{+/+}$mice [46]. Moreover, combined treatment of zoledronic acid with BMP-2 synergistically increased heterotopic bone formation in $\mathrm{Nf1}^{+/-}$mice. In a further approach dual administration of rhBMP-2 and MEK inhibitor PD0325901 strikingly increased callus size and mineralization [47]. However, this approach did not diminish accumulation of fibrotic tissue within the callus. Another approach tested in a posterolateral fusion model of lumbar spine the combination of BMP-2 and zoledronic acid [48]. This approach promoted osteoblastic bone formation and blocked osteoclastic bone resorption maximizing in sum bone formation.

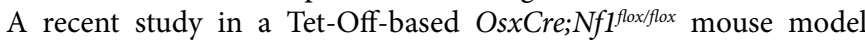
delivers rBMP2-polygycidol as well as Trametinib nanoparticles (MEK inhibitor) locally and largely rescues the previously observed bone healing phenotype [49]. In summary, combinatorial approaches appear very promising for treating fracture healing defects in NF1 mouse models.

\section{Exploratory clinical studies of NF1 pseudarthrosis}

Several human studies with NF1 pseudarthrosis patients explored supplementary therapies after surgery. A pilot study, administering rhBMP-7 (OP-1) and pamidronate or zoledronic acid after surgery of congenital tibia pseudarthrosis, demonstrated a positive healing outcome for NF1 patients [50]. In another follow-up study 16 congenital NF1 patients with pseudarthrosis underwent surgery and were subsequently treated with rhBMP-2 soaked collagen sponges at the site of surgery [51]. Some of the NF1 patients refractured, required a second surgery or were eventually amputated. However, three NF1 patients with surgery and rhBMP-2 treatment healed suggesting that induction of bone formation with rhBMP-2 is a viable therapeutic option. A further controlled trial study tested the impact of rhBMP-7 after surgery, intramedullary fixation, and autologous bone grafting [52]. This study did not detect a difference in healing time and post-operative improvements after rhBMP-7 application. Treatment with osteogenic BMPs appears to support fracture healing in pseudarthrosis; however, the applied surgical procedure strongly determines surgery outcome $[50,10]$.

Some clinical trials assessing NF1 bone features and therapeutic approaches are currently performed or were recently finished (https:// clinicaltrials.gov). Briefly, the NF107-BMP2 study aims to test the osteogenic effect and safety of BMP-2 application in pediatric NF1 tibial pseudarthrosis (NCT02718131). The Vit D Bone NF1 study explores the impact of systematic, 2 year vitamin D supplementation in NF1 individuals with vitamin D deficiency (NCT01968590). A genetic evaluation aims to establish early genetic markers of adolescent idiopathic scoliosis in NF1 patients with scoliosis (NCT01776125). Another study assessed the impact of physical training of pediatric NF1 patients on their musculoskeletal capabilities (NCT01058330). This study is of high interest as preventive physical training or adapted 
Citation: Seifert W, Kolanczyk M, Kühnisch J (2016) The Skeletal Phenotype in Neurofibromatosis Type 1 - Structural Defects, Molecular Mechanisms and Therapeutic Approaches. Int J Surg Surgical Porced 1: 113. doi: http://dx.doi.org/10.15344/ijssp/2016/113

Page 6 of 7

physical behavior during skeletal development may improve bone quality and mechanical strength.

\section{Conclusions}

NF1 is a tumor entity with an incidence of approx. 1:3000 from which approx. $30 \%$ are affected by skeletal signs and $5 \%$ of congenital NF1 cases present with pseudarthrosis $[9,14]$. Thus, in every day praxis consultation of NF1 patients with skeletal symptoms or pseudarthrosis is likely. Before ongoing therapy consultation with an NF1 expert should be performed to validate diagnosis, genetics, and potential individual risk factors. Pre-clinical studies underpin clinical observations showing that NF1 patients may have overall poor bone quality with risk of developing focal defects. Thus, surgical procedures need to be tailored to match the specific individual patient phenotype.

In 2013 Stevenson et al. summarized a consensus for surgical and pharmacological treatment of NF1 tibial pseudarthrosis [10]. The surgical recommendation comprise: i) debridement of fibrous tissue from the pseudarthrotic site to healthy bone, ii) rigid stabilization of the fracture site, and iii) grafting of the fracture site with an autologous iliac crest derived bone transplant. It is critical that the surgical procedure achieves rigid stabilization of the fracture site with case-specific considerations. Pharmacological approaches possibly supporting bone fracture healing post NF1 pseudarthrosis surgery comprise: i) BMP-2 or BMP-7 treatment, ii) bisphosphonate administration, and iii) vitamin $\mathrm{D}$ supplementation [10]. Some of these pharmacological approaches have adverse effects and do not specifically target the RAS/MAPK/ERK pathway which is hyperactivated due to loss of $N f 1$ function $[2,3,29]$.

Results of Prx1Cre; $N f f^{f l o x f f l o x}$ mouse model studies revealed that altered bone vascularization in a critical way impacts the macroporosity of cortical bone and diminishes the mechanical strength $[3,36]$. Thus, the mechanistic interplay of the blood vessel system with bone tissue during development and homeostasis is a promising target for further research. In Colla $1 \mathrm{Cre} ; \mathrm{Nf1} 1^{f l o x}$ fflox osteoblasts collagen secretion is amplified and mineralization diminished suggesting altered bone matrix composition [29]. Moreover, altered PPi levels have been identified as causative factor for hyperostoidosis in Col2a1Cre; $f^{1} f^{f l o x f f l o x}$ mice [32]. Thus, the interplay between extracellular matrix and cellular differentiation processes of $\mathrm{Nf1}$ deficient cells would expand our pathomechanistic understanding. In addition to defective mineralized tissue formation, ablation of Nf1 leads to accumulation of fibrotic tissue during fracture healing $[30,42]$. This process starts during the initial phase of wound healing. It will be important to address in future studies whether alteration of early post-injury inflammation events contributes to pseudarthrosis formation. Similarly, systemic and local impact of NF1 tumors on the skeletal system development and homeostasis remains to be investigated.

\section{Competing Interests}

The authors declare that they have no competing interests.

\section{References}

1. Ratner N, Miller SJ (2015) A RASopathy gene commonly mutated in cancer: the neurofibromatosis type 1 tumour suppressor. Nat Rev Cancer 15: $290-301$.
2. Rodríguez-Carballo E, Gámez B, Ventura F (2016) p38 MAPK Signaling in Osteoblast Differentiation. Front Cell Dev Biol 4: 40 .

3. Kolanczyk M, Kossler N, Kühnisch J, Lavitas L, Stricker S, et al. (2007) Multiple roles for neurofibromin in skeletal development and growth. Hum Mol Genet 16: 874-886.

4. Friedrich RE, Holstein AF, Middendorff R, Davidoff MS (2012) Vascular wall cells contribute to tumourigenesis in cutaneous neurofibromas of patients with neurofibromatosis type 1. A comparative histological, ultrastructural and immunohistochemical study. Anticancer Res 32: 2139-2158.

5. De Raedt T, Beert E, Pasmant E, Luscan A, Brems H, et al. (2014) PRC2 loss amplifies Ras-driven transcription and confers sensitivity to BRD4based therapies. Nature 514: 247-251.

6. Emmerich D, Zemojtel T2, Hecht J3, Krawitz P4, Spielmann M4, et al. (2015) Somatic neurofibromatosis type 1 (NF1) inactivation events in cutaneous neurofibromas of a single NF1 patient. Eur J Hum Genet 23: 870-873.

7. Korf BR (2013) Neurofibromatosis. Handb Clin Neurol 111: 333-340.

8. Uusitalo E, Hammais A, Palonen E, Brandt A, Makela VV, et al. (2014) Neurofibromatosis type 1 gene mutation analysis using sequence capture and high-throughput sequencing. Acta Derm Venereol 94: 663-666.

9. Stevenson DA, Birch PH, Friedman JM, Viskochil DH, Balestrazzi P, et al. (1999) Descriptive analysis of tibial pseudarthrosis in patients with neurofibromatosis 1. Am J Med Genet 84: 413-419.

10. Stevenson DA, Little $D$, Armstrong $L$, Crawford $A H$, Eastwood $D$, et al. (2013) Approaches to treating NF1 tibial pseudarthrosis: consensus from the Children's Tumor Foundation NF1 Bone Abnormalities Consortium. J Pediatr Orthop 33: 269-275.

11. Alwan S, Armstrong L, Joe H, Birch PH, Szudek J, et al. (2007) Associations of osseous abnormalities in Neurofibromatosis 1. Am J Med Genet A 143A: 1326-1333

12. Brunetti-Pierri N, Doty SB, Hicks J, Phan K, Mendoza-Londono R, et al. (2008) Generalized metabolic bone disease in Neurofibromatosis type I. Mol Genet Metab 94: 105-111.

13. Illés T, Halmai V, de Jonge T, Dubousset J (2001) Decreased bone mineral density in neurofibromatosis-1 patients with spinal deformities. Osteoporos Int 12: 823-827.

14. Lammert M, Kappler M, Mautner VF, Lammert K, Störkel S, et al. (2005) Decreased bone mineral density in patients with neurofibromatosis 1 Osteoporos Int 16: 1161-1166

15. Seitz S, Schnabel C, Busse B, Schmidt HU, Beil FT, et al. (2010) High bone turnover and accumulation of osteoid in patients with neurofibromatosis 1. Osteoporos Int 21: 119-127.

16. Stevenson DA, Carey JC, Viskochil DH, Moyer-Mileur LJ, Slater H, et al. (2009a) Analysis of radiographic characteristics of anterolateral bowing of the leg before fracture in neurofibromatosis type 1. J Pediatr Orthop 29: 385-392.

17. Tucker T, Schnabel C, Hartmann M, Friedrich RE, Frieling I, et al. (2009) Bone health and fracture rate in individuals with neurofibromatosis 1 (NF1). J Med Genet 46: 259-265.

18. Kuorilehto T, Pöyhönen M, Bloigu R, Heikkinen J, Väänänen K, et al. (2005) Decreased bone mineral density and content in neurofibromatosis type 1: lowest local values are located in the load-carrying parts of the body. Osteoporos Int 16: 928-936.

19. Lammert M, Friedman JM, Roth HJ, Friedrich RE, Kluwe L, et al. (2006) Vitamin $D$ deficiency associated with number of neurofibromas in neurofibromatosis 1. J Med Genet 43: 810-813.

20. Alwan S, Tredwell SJ, Friedman JM (2005) Is osseous dysplasia a primary feature of neurofibromatosis 1 (NF1)? Clin Genet 67: 378-390.

21. Chappard D, Baslé MF, Legrand E, Audran M (2011) New laboratory tools in the assessment of bone quality. Osteoporos Int 22: 2225-2240.

22. Ritchie RO (2011) The conflicts between strength and toughness. Nat Mater 10: 817-822.

23. Ducroquet RL (1937) A propos des pseudoarthroses et inflexions conge'nitales du tibia. Mem Acad Chir (Paris) 63: 863-868. 
Citation: Seifert W, Kolanczyk M, Kühnisch J (2016) The Skeletal Phenotype in Neurofibromatosis Type 1 - Structural Defects, Molecular Mechanisms and Therapeutic Approaches. Int J Surg Surgical Porced 1: 113. doi: http://dx.doi.org/10.15344/ijssp/2016/113

23. Crawford AH Jr, Bagamery N (1986) Osseous manifestations of neurofibromatosis in childhood. J Pediatr Orthop 6: 72-88.

24. Rudicel S (1987) The orthopaedic manifestations of neurofibromatosis. Conn Med 51: 221-222.

25. Stevenson DA, Zhou H, Ashrafi S, Messiaen LM, Carey JC, et al. (2006) Double inactivation of NF1 in tibial pseudarthrosis. Am J Hum Genet 79: 143-148.

26. Stevenson DA, Viskochil DH, Carey JC, Slater H, Murray M, et al. (2009b) Tibial geometry in individuals with neurofibromatosis type 1 without anterolateral bowing of the lower leg using peripheral quantitative computed tomography. Bone 44: 585-589.

27. Yu X, Chen S, Potter OL, Murthy SM, Li J, et al. (2005) Neurofibromin and its inactivation of Ras are prerequisites for osteoblast functioning. Bone 36: $793-802$

28. Elefteriou F, Benson MD, Sowa H, Starbuck M, Liu X, et al. (2006) ATF4 mediation of NF1 functions in osteoblast reveals a nutritional basis for congenital skeletal dysplasiae. Cell Metab 4: 441-451.

29. Kolanczyk M, Kühnisch J, Kossler N, Osswald M, Stumpp S, et al. (2008) Modelling neurofibromatosis type 1 tibial dysplasia and its treatment with lovastatin. BMC Med 6: 21.

30. Wang W, Nyman JS, Ono K, Stevenson DA, Yang X, et al. (2011) Mice lacking Nf1 in osteochondroprogenitor cells display skeletal dysplasia similar to patients with neurofibromatosis type I. Hum Mol Genet 20: 3910 3924.

31. de la Croix Ndong J, Makowski AJ, Uppuganti S, Vignaux G, Ono K, et al (2014) Asfotase-alpha improves bone growth, mineralization and strength in mouse models of neurofibromatosis type-1. Nat Med 20: 904-910.

32. Wang W, Nyman JS, Moss HE, Gutierrez G, Mundy GR, et al. (2010) Loca low-dose lovastatin delivery improves the bone-healing defect caused by Nf1 loss of function in osteoblasts. J Bone Miner Res 25: 1658-1667.

33. Zhang W, Rhodes SD, Zhao L, He Y, Zhang Y, et al. (2011) Primary osteopathy of vertebrae in a neurofibromatosis type 1 murine model. Bone 48: $1378-1387$

34. Kossler N, Stricker S, Rödelsperger C, Robinson PN, Kim J, et al. (2011) Neurofibromin (Nf1) is required for skeletal muscle development. Hum Mo Genet 20: 2697-2709.

35. Kuhnisch J, Seto J, Lange C Schrof S, Stumpp S, et al. (2014a) Multiscale, Converging Defects of Macro-Porosity, Microstructure and Matrix Mineralization Impact Long Bone Fragility in NF1. PLoS One 9: e86115.

36. Kuhnisch J, Seto J, Lange C, Stumpp S, Kobus K, et al. (2014b) Neurofibromin inactivation impairs osteocyte development in Nf1Prx1 and Nf1Col1 mouse models. Bone 66:155-62.

37. Benichou O, Lord SR (2016) Rationale for Strengthening Muscle to Prevent Falls and Fractures: A Review of the Evidence. Calcif Tissue Int 98: 531 545.

38. Milne N (2016) Curved bones: An adaptation to habitual loading. J Theor Biol 407: 18-24.

39. Stevenson DA, Allen S, Tidyman WE, Carey JC, Viskochil DH, et al. (2012) Peripheral muscle weakness in RASopathies. Muscle Nerve 46: 394-399.

40. Sullivan K, El-Hoss J, Quinlan KG, Deo N, Garton F, et al. (2014) NF1 is a critical regulator of muscle development and metabolism. Hum Mol Genet 23: $1250-1259$.

41. Schindeler A, Morse A, Harry L, Godfrey C, Mikulec K, et al. (2008) Models of tibial fracture healing in normal and Nf1-deficient mice. J Orthop Res 26: 1053-1060.

42. El-Hoss J, Cheng T, Carpenter EC, Sullivan K, Deo N, et al (2014) A Combination of rhBMP-2 (Recombinant Human Bone Morphogenetic Protein-2) and MEK (MAP Kinase/ERK Kinase) Inhibitor PD0325901 Increases Bone Formation in a Murine Model of Neurofibromatosis Type Pseudarthrosis. J Bone Joint Surg Am 96: e117.

43. Sharma R, Wu X, Rhodes SD, Chen S, He Y, et al. (2013) Hyperactive Ras/MAPK signaling is critical for tibial nonunion fracture in neurofibromindeficient mice. Hum Mol Genet 22: 4818-4828.
45. Vukicevic S, Oppermann H, Verbanac D, Jankolija M, Popek I, et al. (2014) The clinical use of bone morphogenetic proteins revisited: a novel biocompatible carrier device OSTEOGROW for bone healing. Int Orthop 38: $635-647$

46. Schindeler A, Ramachandran M, Godfrey C, Morse A, McDonald M, et al. (2008b) Modeling bone morphogenetic protein and bisphosphonate combination therapy in wild-type and Nf1 haploinsufficient mice. J Orthop Res 26: 65-74

47. El-Hoss J, Sullivan K, Cheng T, Yu NY, Bobyn JD, et al. (2011) A murine model of neurofibromatosis type 1 tibial pseudarthrosis featuring proliferative fibrous tissue and osteoclast-like cells. J Bone Miner Res 27 68-78.

48. Bobyn J, Rasch A, Kathy M, Little DG, Schindeler A (2014) Maximizing bone formation in posterior spine fusion using rhBMP-2 and zoledronic acid in wild type and NF1 deficient mice. J Orthop Res 32: 1090-1094.

49. de la Croix Ndong J, Stevens DM, Vignaux G, Uppuganti S, Perrien DS, et al. (2015) Combined MEK inhibition and BMP2 treatment promotes osteoblast differentiation and bone healing in Nf1Osx -/- mice. J Bone Miner Res 30: 55-63.

50. Birke O, Schindeler A, Ramachandran M, Cowell CT, Munns CF, et al. (2010) Preliminary experience with the combined use of recombinant bone morphogenetic protein and bisphosphonates in the treatment of congenital pseudarthrosis of the tibia. J Child Orthop 4: 507-517.

51. Richards BS, Anderson TD (2016) rhBMP-2 and Intramedullary Fixation in Congenital Pseudarthrosis of the Tibia. J Pediatr Orthop

52. Das SP, Ganesh S, Pradhan S, Singh D, Mohanty RN (2014) Effectiveness of recombinant human bone morphogenetic protein-7 in the management of congenital pseudoarthrosis of the tibia: a randomised controlled trial. Int Orthop 38: 1987-1992. 